\title{
DZIECKo w TwórCZości KSIĘDZA JaNa TwardowsKIEgo
}

Ksiądz Jan Twardowski to poeta religijny. Jego poezja jest arcydziełem zachwytu nad pięknem świata i jego stworzenia. Miejsce szczególne w jego twórczości zajmuje dziecko. Helena Zaworska zauważyła:

żeby wierzyć, kochać, mieć nadzieję, nie wystarczy rozmyślać nad trzema cnotami ewangelicznymi. Trzeba na to dziecięcej, nie kontrolowanej przez rozum wyobraźni, spontanicznej uczuciowości. Dzieciństwo mija, ale dziecięctwo [podkr. - H. Z.] jest całożyciowym skarbem, podstawą wybranej przez Twardowskiego "wielkiej wiary malutkiej«, która potrafi przenosić góry. [...] Nasza dzisiejsza wiara ostrożna pragnie znaleźć ustalone normy, zakreślić wyraźne granice, zabezpieczyć się przed ryzykiem i zwątpieniem. Wiara malutka zaś skacze z dziecinnym uniesieniem w Nieznane, pędzi bez strachu i tchu' ${ }^{1}$.

Ksiądz-poeta (duchowy spadkobierca Hansa Christiana Andersena i Janusza Korczaka) ${ }^{2}$ poświęcił dziecku olbrzymią część swojej poezji. Pisał on o dziecku, ale przede wszystkim dla i do dziecka. Twórczość ta jest także bardzo chętnie czytana przez dorosłych, którzy dzięki odkrywaniu w sobie dziecka, mogą na nowo i w sposób pełniejszy poznawać świat. Jan Twardowski, jak zauważył Jan Bończa-Szabłowski, „sam siebie nazywa "rozpieszczonym dzieckiem"”3. Jak stwierdził Andrzej Sulikowski:

\footnotetext{
* Katarzyna Stępińska - absolwentka jednolitych studiów magisterskich na Uniwersytecie Gdańskim na kierunku filologia polska ze specjalizacją edytorską i nauczycielską, a także na kierunku slawistyka (z kierunkowym językiem serbskim). Od 2009 roku jest słuchaczką Filologicznego Studium Doktoranckiego na Wydziale Filologicznym Uniwersytetu Gdańskiego ze specjalnością językoznawczą (pisze swoją rozprawę doktorską na temat językowego obrazu kwiatów w polszczyźnie i serbszczyźnie), a od 2014 roku jest tutorem akademickim. W czasie studiów magisterskich i doktoranckich brała udział w konferencjach naukowych (większość z nich o charakterze międzynarodowym) i publikowała artykuły naukowe zarówno z zakresu językoznawstwa, jak i z literaturoznawstwa i kulturoznawstwa, wiele z nich o charakterze porównawczym na materiale polskim i serbskim. Redagowała tom Rośliny w języku i kulturze. W ostatnich latach realizowała trzy granty naukowe związane z językowym obrazem kwiatów w polszczyźnie i serbszczyźnie oraz bałkańską różnorodnością. W polu jej zainteresowań naukowych leżą badania porównawcze języków słowiańskich, polszczyzna XXI wieku, problemy społeczne w słowiańskiej literaturze najnowszej (zwłaszcza w dramacie), wielokulturowość Bałkanów (przede wszystkim Bośni wraz z jej stolicą — Sarajewem), a także edukacja spersonalizowana oraz tutoring przedszkolny, szkolny i akademicki.

${ }^{1}$ H. Zaworska, Trzcina czująca, [w:] J. Twardowski, Biedroneczko leć do nieba. Lekcja literatury z Helena Zaworską, Kraków 1997, s. 7.

${ }^{2}$ Por. A. Sulikowski, Wokót dzieciństwa, [w:] tenże, Świat poetycki księdza Jana Twardowskiego, Lublin 1995, s. 160.

${ }^{3}$ J. Bończa-Szabłowski, Poeta świętych i grzeszników, „Rzeczpospolita” 2000, nr 94, z. 20, IV.
} 
[...] z punktu widzenia Chrystusa Zmartwychwstałego [...] każdy czytelnik okazuje się w swej istocie właśnie »dzieckiem Bożym«. W taki sposób próbuje patrzeć na swego odbiorcę ks. Jan Twardowski od początku swej twórczości literackiej.

Człowiek zaś w jego poezji jest nieustannie przez całe życie dzieckiem. Człowiek najmniejszy i najmłodszy w poezji tego twórcy, to, jak zauważyła Jolanta Ługowska:

[...] nie tylko swoisty "projekt« czy zespół intelektualnych i emocjonalnych predyspozycji, odkrytych przez dorosłego w procesie swoistej introspekcji. Poetę interesuje przede wszystkim dziecko ujmowane w całym bogactwie jego psychofizycznej aktywności, obserwowane z ogromną życzliwością — w zabawie, dziecięcych psotach, a także w modlitewnym zamyślenius.

Dziecko jest tematem szczególnym w literaturze, jest też szczególnym odbiorcą. Celem obecnych rozważań jest namysł nad poezją księdza Twardowskiego adresowaną do dzieci, a zwłaszcza nad wierszami z tomików: Zeszyt w kratkę, Patyki i patyczaki, Kasztan dla milionera, Święty Mikołaj na Gwiazdkę, Kubek z jednym uchem, Dzieciom, Najmłodsi poeci i malarze, Dwa osiotki, Nie tylko wrona chodzi zdziwiona, Ile stońca $w$ stoneczniku, powiedz, drogi mój chłopczyku?, Uśmiech na gwiazdkę, Pacierz z Ks. Twardowskim.

Dziecko jest tu kimś, kto nieustannie się dziwi, kto wciąż zadaje mnóstwo pytań, kto chce poznawać świat i zachwycać się nim, ponieważ wszystko, co widzi, ma znamiona czegoś nowego, pełnego tajemnicy. Człowiek dorosły może uczyć się od dziecka tego ciągłego i spontanicznego zachwytu nad rzeczywistością, odkrywania piękna we wszechświecie, traktowania wszystkiego jak absolutną nowość; może uczyć się szczególnej wrażliwości i pełnej ufności, właściwych tylko tym najmniejszym. Wiersze Twardowskiego przywołują figurę dziecka jako wzór do naśladowania dla dorosłych, jako zachętę dla nich do odnalezienia w sobie dziecka.

Wiersz Naucz się dziwić, mimo że adresowany do młodego czytelnika, jest także nauką dla dorosłych. Jak zauważył Waldemar Smaszcz — „pojawia się tu słowo kluczowe dla całej twórczości kapłana-poety »dziwić się« (obocznie "zdumiewać się«), występujące w wielu utworach" ". Twardowski uczył, by stanąć w postawie dziecka, które, w sposób bardzo naturalny i szczery, dziwi się wszystkiemu. Słowa tego utworu zachęcają:

\footnotetext{
Naucz się dziwić w kościele, że Hostia Najświętsza tak mała, że w dłonie by ją schowała najniższa dziewczynka w bieli
}

\footnotetext{
${ }^{4}$ A. Sulikowski, dz. cyt., s. $156-157$.

${ }^{5}$ J. Ługowska, Dziecko w poezji Jana Twardowskiego, [w:] To, co Boskie, to, co ludzkie, red. R. Pyzałka, Wrocław 1996, s. 27.

${ }^{6}$ W. Smaszcz, Ks. Jan Twardowski. Poeta nadziei. Życie i twórczość, Białystok 2003, s. 53-54.

${ }^{7}$ J. Twardowski, Naucz się dziwić, [w:] tenże, Utwory zebrane, t. 2, Kraków 2002, s. 9.
} 
Sam ksiądz Twardowski mówił: „Dziecko potrzebuje śmiechu, potrzebuje akceptacji świata, podziwu dla życia. Potrzebny, konieczny jest zachwyt!"8. Te niewinne istoty uczą zatrzymywać się nad tajemnicami codzienności, nad rzeczami najmniejszymi, choć tak ważnymi, jak choćby ukryty w hostii Chrystus, przed którym „rzesza upada”, a rozszalali chłopcy „milkną jak gawrony, / bo ich kościół zadziwia powagą”.

Literacka katecheza Twardowskiego polega na traktowaniu dziecka z pełnym szacunkiem, rozumiał on potrzeby i zamiłowania młodych, także tych najmniejszych. W utworze $O$ maluchach dał wyraz pełnej akceptacji dla fantazji dzieci, które w czasie kazania nie słuchały grzmiącego $\mathrm{z}$ ambony kapłana, lecz wymyślały sobie przeróżne ciekawsze zajęcia: „oswajają sterczące z ławek zdechłe parasole”, „pokazują różowy język", „liczą pobożne nogi pań” i przede wszystkim nieustannie się dziwią, wszystko ich zaciekawia, wszystko jest dla nich godne uwagi. Być może niektórym zdawałoby się, że nie wypada się tak zachowywać w kościele, ale ksiądz Jan przypomina ewangeliczną prawdę, że „Jezus brał dzieci z powagą na kolana”"10.

Najmłodsi, jak pisał Twardowski w utworze Modlitwa dzieci, „widzą dalej i więcej”, dlatego są tymi, którzy mogą nas uchronić od obłudy, wiecznego narzekania i smutku. Te istotki, zachwycając się otaczającym światem, wskazują na dobre aspekty ludzkiego życia, pomagają człowiekowi dorosłemu uwolnić się od zmartwień dnia codziennego, które w istocie często są wywołane faktem, że nie potrafi on już radować się drobnostkami. Dzieci, wręcz przeciwnie, cieszy wiele, ksiądz-poeta wymienił, co dokładnie: „pole różowe / kiedy wschodzi słońce / nagietek który przekwita w październiku / pszczoły dokładnie złote / leszczyna co wydaje jednocześnie kwiaty i orzechy" ${ }^{11}$.

$\mathrm{Z}$ wiary malutkiej, z wiary dziecięcej, wypływa olbrzymie dobrodziejstwo, ogromna ufność. Dziecko bowiem, jak mówił ksiądz-poeta, „wierzy, że jest Bóg, wierzy, że nie jest samo"12.

Wiara, której dorośli mają uczyć się od najmłodszych, jest pełna zachwytu nad światem, nad codziennością, nad wspaniałym dziełem stworzenia; przepełnia ją ufność — taka ufność, jaką ma dziecko wobec matki. Dziecięca wiara jest rozumna, choć nie ma podstaw teologicznych.

Piękno i doskonałość Bożego stworzenia łączy ziemię z niebem. Biedroneczka z wiersza Do nieba leci do niebiańskiego świata:

Po wiersz tak prosty że każdy zrozumie

po krzyż zwykły wystrugany z drzewa

\footnotetext{
${ }^{8}$ Tenże, Ważny jest uśmiech i łza. Z księdzem Janem Twardowskim rozmawia Grzegorz Leszczyński, „Guliwer" 1991, nr 2, s. 22.

${ }^{9}$ Tenże, Naucz się dziwić, s. 9.

${ }^{10}$ Tenże, O maluchach, [w:] tenże, Utwory zebrane, t. 2, s. 23.

${ }^{11}$ Tenże, Modlitwa dzieci, [w:] tamże, s. 76.

${ }^{12}$ Tenże, Wiara dziecięca, [w:] tenże, H. Zaworska, Jestem bo jesteś. Z księdzem Janem Twardowskim rozmawia Helena Zaworska, Kraków 1999, s. 12.
} 
po wiarę już pewną bo dowodów nie ma

po szczęście bez rozgłosu pieniędzy chleba ${ }^{13}$.

W centrum tego makrokosmosu znajduje się uśmiechający się Jezus Chrystus, który jest światłem i przedłużeniem uśmiechu Boga. Jak stwierdziła Ługowska:

Jezus uśmiechnięty — to wyraz akceptacji człowieka jako dziecka Bożego, dowód miłości Najwyższego do niedoskonałej istoty ludzkiej, a także zapewnienie, że otaczający świat, jako dzieło Boga, jest dla człowieka przyjazny i bezpieczny. To także źródło autorskiego optymizmu i rozbawionej tolerancji dla poczynań dziecka wyzwolonego ze sztywnego gorsetu wyuczonych reguł bon ton $u^{14}$.

Twardowski okazał akceptację i szacunek dziecięcemu czytelnikowi również przez fakt nieukrywania przed nim prawdy; otwarcie mówił mu o cierpieniu wpisanym w chrześcijaństwo i o odczuwaniu wielu innych negatywnych uczuć z tym związanych. Sam poeta pisał: „W życiu najlepiej, kiedy jest nam dobrze i źle. Kiedy jest nam tylko dobrze - to niedobrze" ${ }^{15}$. Ksiądz-poeta uczył dzieci tej jakże trudnej prawdy wpisanej w chrześcijaństwo — zgody na cierpienie, mówił wprost, że Jezus był tym, który nosił „koronę cierniową”; w wierszu Tak, znanym również pod tytułem Pierwsza Komunia, zachęcał: „święte cierpienie pocałuj w rączkę / Bogu się mówi — tak” ${ }^{16}$, a w utworze Do albumu posuwał się dalej, uczył dziękować za cierpienie:

\section{Podziękuj za cierpienie \\ czy umiesz czy nie umiesz \\ bez niego nigdy nie wiesz \\ ile miłość kosztuje ${ }^{17}$.}

Ta nauka o cierpieniu nie ma jednak wprowadzać smutku w życie, przeciwnie, jak sam poeta, w utworze zatytułowanym Nie smutek, pisał:

Jeśli w wierszach moich znajdziesz smutek -

to po prostu bolała mnie głowa,

korek wysiadk, wygłupiał się czajnik,

za wcześnie zbudziła krowa ${ }^{18}$.

To jedno, co można znaleźć w jego utworach, a co ma smutne zabarwienie, to samotność i „żal, że serce nie poszło do serca, / żal, że dusza odeszła od duszy” ${ }^{19}$. Z drugiej jednak strony Twardowski wskazuje na osoby i rzeczy, dzięki którym mógł

\footnotetext{
${ }^{13}$ Tenże, Do nieba, [w:] tenże, Utwory zebrane, t.3, s. 38.

${ }^{14}$ J. Ługowska, dz. cyt., s. 33.

${ }^{15} \mathrm{~J}$. Bończa-Szabłowski, $d z$. cyt.

${ }^{16} \mathrm{~J}$. Twardowski, Pierwsza Komunia [w:] tenże, Utwory zebrane, t. 3, s. 26.

${ }^{17}$ Tenże, Do albumu, [w:] tamże, t. 2, s. 134.

${ }^{18}$ Tenże, Nie smutek, [w:] tamże, s. 175.

${ }^{19}$ Tamże, s. 175.
} 
nie czuć się samotny. W wierszu Matka Teresa z Kalkuty, skierowanym do tej błogosławionej, czytamy „nikt nie jest samotny z tobą” ${ }^{20}$.

Ksiądz Jan w swoich wierszach bardzo często odnosił się do błogosławionych i świętych, przybliżając ich osoby dziecięcemu czytelnikowi: przedstawiał świętego Józefa, który „dąsa się wyraźnie, gdy Matce Bożej różę wystrojoną niosą”21; świętego Tomasza - niedowiarka, którego serce przemieniał Zmartwychwstały Chrystus; świętego Wojciecha, który „zginął za wiarę”, a teraz „Polski pilnuje”22; patrona zoologów i ornitologów świętego Franciszka; specjalistę od rzeczy zgubionych — świętego Antoniego, który ma moc „przywrócić kubek z jednym uchem”23; świętego Stanisława Kostkę, który „żył krótko / Jezusem przejęty”24; opiekunkę trędowatych Matkę Teresę z Kalkuty.

Poeta tłumaczył młodym czytelnikom Słowo Boże, starał się przełożyć Biblię na realia współczesne. W wierszu Mamusia zamiast Trzech Mędrców, niosących złoto, mirrę i kadzidło, przedstawił uczonych, doktorów i docentów, przynoszących dolary, komputer i video. Utwór $O$ Mędrcach opowiadał zaś o królach, którzy przybyli do stajenki, „plackiem padli” i zaraz odjechali; „wół miał pretensje”, że nie ratowali oni Chrystusa przed Herodem, ale osiołek zabawnie strofował go: „puknij się w głowę [...] / bo przecież Matka Boska czuwa"25. Inny wiersz, związany z tematem wędrujących do żłóbka Trzech Mędrców to Trzy królowe, opowiadający o żonach Baltazara, Kaspra i Melchiora, czekających na swoich mężów, którzy ufni w znak Pana, podążyli do stajenki. Z kolei pastuszków przy żłóbku przedstawił poeta w przestrzeni miejskiej, w czasie terá́niejszym - tytułowi Pasterze dochodzili pieszo do swego celu, oddali Dzieciątku wszystko, co mieli, choć nie mieli nic.

W wierszu Chrzest w Jordanie poeta opowiadał o tym, jak Jan Chrzciciel chrzcił ludzi woda; tłumaczył dzieciom, że ci wszyscy, którzy przychodzili nad wodę „chcieli umyć nie tylko ciało, / ale brudne serca i dusze" ${ }^{26}$. Ksiądz Twardowski uczył młodego czytelnika, że i on powinien mieć obmyte serce, „by nigdy nie dokuczać mamusi” i aby być podobnym do Chrystusa, który jest „wśród brudasów, czystszy niż anio»"27.

Ksiądz Jan opowiadał dzieciom również historie ze Starego Testamentu, jak choćby tę o Arce Noego czy o Mojżeszu, wrzuconym do rzeki „z pupką gołą”28. Wszystkie te obrazy, bardzo humorystyczne, pomagają młodemu czytelnikowi w zrozumieniu

\footnotetext{
${ }^{20}$ Tenże, Matka Teresa $z$ Kalkuty, [w:] tamże, s. 171.

${ }^{21}$ Tenże, Róża, [w:] tamże, s. 26.

${ }^{22}$ Tenże, O Świętym Wojciechu, [w:] tamże, t. 3, s. 45.

${ }^{23}$ Tenże, Kubek, [w:] tamże, t. 2, s. 91.

${ }^{24}$ Tenże, Mało czasu, [w:] tamże, t. 3, s. 222.

${ }^{25}$ Tenże, Mamusia, [w:] tamże, t. 2, s. 82.

${ }^{26}$ Tenże, Chrzest w Jordanie, [w:] tamże, t. 3, s. 21-22.

${ }^{27}$ Tamże, s. 21-22.

${ }^{28}$ Tenże, $O$ Mojżeszu, [w:] tamże, t. 1, s. 201.
} 
trudnych pojęć, a także w lepszym wyobrażeniu dziejów zapisanych w Piśmie Świętym i przeniesieniu ich w czasy dzisiejsze.

Jan Twardowski poruszył także inne ważne tematy, które zdawałoby się są przeznaczone przede wszystkim dla dorosłego czytelnika. Ten poeta nie cofnął się nawet przed problemem beznadziei życia, prowadzącej do samobójstwa. W utworze Sześć listków opowiadał o wujku, który przygotował sznur, aby się powiesić, bo nie wiedział ,jak żyć — kiedy czarne wszystko" 29 , ale zaraz potem dodał, że „to nie prawda”, bo Pan Bóg zsyła do pogrążonych w rozpaczy swe stworzenia i daje pocieszenie.

Poeta mówił także otwarcie o posłuszeństwie, o przebaczeniu i pojednaniu, o życiu w ubóstwie i czystości; propagował wiarę, miłość, która „światło zapala” i nadzieję, „która uczy czekać pomaleńku”30. W utworze Jeśli nie do końca, propagując miłość trwałą i przebaczająca, tłumaczył: „Kto do końca nie kocha / ten odchodzi paskudny / i wszystko źle”, uczy nas dobroci, życzliwości i miłości do: „wysokiego, / chudego i pucołowatego, / krzywego i w ucho szczypanego, / jak rydz zdrowego, / na świnkę chorego, / po kolei każdego" ${ }^{11}$. Razem z dziećmi modli się do Ducha Świętego: „żeby nie było ludzi zagniewanych, / żyjących jak pies z kotem, / dokuczających sobie tam i z powrotem" ${ }^{32}$. Ksiądz Twardowski pomagał dzieciom we wprowadzaniu w ich życie przykazania miłości, które dał Chrystus, „byśmy się wzajemnie miłowali, tak jak On nas umiłował" ${ }^{3}$, byśmy „miłowali swego bliźniego jak siebie samego"34, tłumaczy dzieciom, że Pan Bóg stworzył człowieka, aby obdarzał miłością innych ludzi. Ludzkie serce bije, ażeby „kochać, a kochać to dawać i przyjmować” ${ }^{35}$; jak mówił sam Twardowski „każda prawdziwa miłość prowadzi do Boga”"36.

Przede wszystkim jednak pokazał Stworzyciela jako Dobrego Ojca, który tuli swe dzieci w ramionach, który kocha i przebacza; w utworze Owieczka i baranek czytamy: „Lecz On cię kocha, / Nie widzi winy” ${ }^{37}$. W wierszach poety można zobaczyć ukrytego pod postacią , „świętego opłatka” Mesjasza, którego powinno się adorować, „, na ołtarzu (nie) zostawiać samego"38, czekać na Niego i widzieć Go jako żywego, stale obecnego i czekającego na swoje dzieci. W utworze Zmarznięty ksiądz-poeta mnożył pytania, na które ludzie sami muszą sobie odpowiedzieć:

\footnotetext{
${ }^{29}$ Tenże, Sześć listków, [w:] tamże, t. 3, s. 25.

${ }^{30}$ Tenże, Prośba, [w:] tamże, s. 197.

${ }^{31}$ Tenże, Jeśli nie do końca, [w:] tamże, s. 74.

${ }^{32}$ Tenże, Wiersz do Ducha Świętego, [w:] tamże, t. 2, s. 211.

${ }^{33}$ Biblia Jerozolimska, Poznań 2006, J 13, 34.

${ }^{34}$ Por. Tamże, Mt 22, 39.

${ }^{35}$ J. Twardowski, Dlaczego? [w:] tenże, Utwory zebrane, t. 2, s. 51.

${ }^{36}$ Tenże, Poeta Wiary, Nadziei i Mitości — ks. Jan Twardowski: wiersze 1932-2002, rozmowa Anny Czachorowskiej z Poeta, Warszawa 2002, s. 9.

${ }^{37}$ Tenże, Owieczka i baranek, [w:] tenże, Utwory zebrane, t. 3, s. 120.

${ }^{38}$ Tenże, Czekanie, [w:] tamże, s. 188.
} 
Czy Jezus nie jest głodny w nas?

Czy karmimy Go miłością?

Czy Jezusowi nie jest w nas zimno?

Czy czasem nasze serce nie wygasa? ${ }^{39}$

W wierszu Czekanie poeta opisał psa, oczekującego z utęsknieniem na swego pana, by na końcu wiersza zachęcić czytelnika do wdzięczności dla tego zwierzęcia, gdyż „uczy jak na Boga czekać” 40 .

Warto zwrócić uwagę na wątek autobiograficzny. Ksiądz Jan miał bogate doświadczenie w pracy z najmłodszymi. Był on katechetą w szkołach specjalnych, w domach dziecka ${ }^{41}$. Wspominając lata pracy z dziećmi upośledzonymi umysłowo, przyznał, że jego wychowankowie „oduczyli go mówić ogólnikami, nauczyli zwracać uwagę na szczególy" ${ }^{42}$. W swoich utworach powracał często do szkolnych sal oraz do swoich uczniów, których wymieniał czasem i z nazwiska. W wierszach księdza Jana odkryć można jego ogromną miłość i sympatię do podopiecznych, obserwować ogromną wdzięczność, jaką miał on dla najmłodszych. Te dzieci uczyły go przecież ciągłego zachwytu i poszukiwania we wszystkim Boga.

Jego wychowankowie nie pozwalali mu też zapomnieć, czym jest wiara dziecka, odkrywając tysiące możliwości poznania Chrystusa, niekoniecznie poprzez mędrkowanie, ale raczej głęboką ufność ${ }^{43}$.

Jak podał Andrzej Sulikowski:

Twardowski wie doskonale, że wszyscy jesteśmy w głębi swego ducha ciągle jeszcze dziecinni i niedojrzali, szukamy po omacku Ojca i chętnie o Nim słuchamy, nawet jeśli miałyby to być zabawne historyjki tylko dla młodych i najmłodszych ${ }^{44}$.

„W gruncie rzeczy pisząc dla dzieci bawi i zaciekawia każdego”5, zarówno dziecko, jak i dorosły, doskonale odbierają tę poezję religijną, bo dzięki niej mogą dotykać Boga i świętości. Poezja księdza Jana, która jest skierowana do dzieci, zmusza także dojrzałych czytelników, byśmy „sercem uklękli” i nie tylko zaczęli wierzyć w cuda, ale także doświadczali tych cudów w swoim życiu. Twardowski uczył widzieć i kochać Boga, który jest „Wszechmogący, bo tak maleńki” ${ }^{46}$. Czytając jego utwory możemy na nowo powrócić do wiary malutkiej i choć na chwilę pozwolić, by serce stało się dziecięcym.

\footnotetext{
${ }^{39}$ Tenże, Zmarznięty, [w:] tamże, t. 2, s. 31.

${ }^{40}$ Tenże, Czekanie, s. 191.

${ }^{41}$ Por. S. Grabowski, Ksiadz Jan Twardowski. Szkice o poecie, Warszawa 1999.

${ }^{42} \mathrm{~J}$. Bończa-Szabłowski, $d z$. cyt.

${ }^{43}$ W. Smaszcz, Jan Twardowski. Kaptan-poeta, Białystok 1991, s. 18.

${ }^{44}$ A. Sulikowski, dz. cyt., s. 178.

${ }^{45}$ Tamże, s. 171.

${ }^{46}$ J. Twardowski, Taki maty, [w:] tenże, Utwory zebrane, t. 3, s. 192.
} 
Katarzyna Stępińska

\section{The Child in the Works of Priest Jan Twardowski}

\section{Summary}

Father Jan Twardowski is a religious poet. His poetry is a masterpiece of wonder at the beauty of the world and its creatures. Children have a special place in his work. Not only he wrote about children, but also he wrote for them. The child in his poetry is someone who is constantly surprised, who is asking a lot of questions, who wants to explore the world and admire him, because everything he sees is something new and full of mystery. His poetry is also very widely read by adults because they can discover a child in themselves and they may again and more fully explore the world.

Słowa kluczowe: ksiądz Jan Twardowski, dziecko, wiara

Keywords: father Jan Twardowski, child, faith 